This is an open access article under the CC BY-NC-ND license (https://creativecommons.org/licenses/by-nc-nd/3.0/) Issue III, November 2020

ISSN 2707-9481

ISBN 978-601-323-207-2

https://doi.org/10.31643/2020.012

Timur Apendiyev

National Academy of Sciences of the Republic of Kazakhstan

E-mail: timur.apendiev@mail.ru

ORCID ID 0000-0002-4279-3921

\title{
During the first World War Germany and Austria -Hungary prisoners of the Aulie Ata county
}

\begin{abstract}
The First World War was the largest event in the history of mankind, which had a significant impact on the fate of many peoples, including states. One of the main factors was the capture of troops and individuals on the front of the war between warring states and the flight of soldiers as a result of the war. During the war, neighboring states, political allies captured each other's armies and citizens. The capture of citizens of each other took place between the Entente and the central powers. The Russian Empire, which was part of the Entente and was considered the main participant in the war, detained people from the central powers. Citizens of the central powers captured during the war were sent to all regions of the Russian Empire, which also extended to the steppe and Turkestan provinces. Based on this, the Turkestan Territory was considered one of the key regions of the Russian Empire, in which Europeans were accepted. In the era of the empire, European prisoners lived in the Aulie ata district of the Turkestan governor general in the SyrDarya region. Representatives of European nationality have lived in the region since the end of the nineteenth century, and this continued during the years of the First World War. During World War I, the Aulie ata district was considered one of the districts where European prisoners and refugees were received. Although the number of prisoners of war from the central powers (Germany, Austria-Hungary) in the Ayulie ata district is small, traces of political prisoners of war still remain from these states. The article discusses the history of prisoners of war deported to Aulie ata district during the war years. The socio-political status of the citizens of Germany and Austria-Hungary who arrived in Aulie ata County, their life is studied. The nationality and surname of the captives will be determined, and their standard of living will be determined.
\end{abstract}

Keywords: Aulie ata, World War I, army, refugees, prisoners, Germany, Austria-Hungary, Germans.

Cite this article as: Apendiyev T., (2020). Birinshi duiniezhuizilik sogys zhildarinda aulie ata uezindegi Germaniya zhane Avstro-Vengria tutkyndary [During the first World War Germany and Austria -Hungary prisoners of the Aulie Ata county]. Challenges of Science. Issue III, p.: 83-90. https://doi.org/10.31643/2020.012

Әпендиев Т.Ә.

Қазақстан Республикасының Ұлттық ғылым академиясы, Алматы қ., Қазақстан

E-mail: timur.apendiev@mail.ru

ORCID ID 0000-0002-4279-3921

\section{Бірінші дүниежүзілік соғыс жылдарында Әулиеата уезіндегі Германия және Австро-Венгрия тұтқындары}

Абстракт. Бірінші Дүниежүзілік соғыс - адамзат тарихындағы аса ірі оқиға, ол мемлекеттермен қатар, көптеген халықтардың тағдырына ерекше ықпал етті. Соның ең негізгі факторларының бірі - соғысушы мемлекеттер арасында әскерилер мен жеке азаматтардың соғыс майданында тұтқынға түсуі және жауынгерлердің соғыстан қашуы. Соғыс кезінде бір-бірімен жақын көрші, саяси одақтас болған мемлекеттер бірбірінің әскерлері мен азаматтарын тұтқынға түсіріп отырды. Бір-бірінің азаматтарын тұтқынға алу Антанта мен Орталық державалар арасында көптеп орын алды. Антанта құрамында болып, соғыстың басты қатысушысы саналған Ресей империясы Орталық державалардан шыққан азаматтарды тұтқынға алып отырды. Соғыс кезінде 
тұтқынға түскен Орталық державалардың азаматтары Ресей империясының әр аймақтарына жіберіліп, соның ішінде Дала өлкесі мен Түркістан өлкесіне де таралды. Осының негізінде Түркістан өлкесі Ресей империясының құрамында еуропалық ұлт өкілдерін қабылдаған басты аймақтардың бірі саналды. Империялық дәуірде Түркістан генерал-губернаторлығының Сырдария облысына қарасты болған Әулиеата уезінде еуропалық тұтқындар өмір сүрген. Аймақта XIX ғасырдың соңынан бастап еуропалық ұлт өкілдері өмір сүріп, ол жағдай Бірінші Дүниежүзілік соғыс жылдарында да өз жалғасын тапты. Бірінші Дүниежүзілік соғыс жылдарында Әулиеата уезі еуропалық соғыс тұтқындары мен босқындарын қабылдаған аудандардың бірі болды. Әулиеата уезіне Орталық державалардан (Германия, Австро-Венгрия) келген соғыс тұтқындарының қатары аз болғанымен, бұл аймақта аталған мемлекеттерден келген саяси-әскери тұтқындардың өзіндік іздері қалған. Мақалада соғыс жылдарында Әулиеата уезіне жер аударылған соғыс тұтқындарының тарихы қарастырылады. Әулиеата уезіне келген германиялық және австро-венгриялық азаматтардың саяси-әлеуметтік жағдайы мен олардың тұрмысы және өмір тағдыры зерттеледі. Тұтқын болып келген азаматтардың ұлты мен тегі айқындалып, олардың өмір сүру деңгейі көрсетіледі.

Түйін сөздер: Әулиеата, Бірінші Дүниежүзілік соғыс, Әскер, Босқын азаматтар, Тұтқындар, Германия, Австро-Венгрия, Немістер.

Кіріспе. Дала өлкесін және Түркістан өлкесінің үлкен бөлігін қамтыған қазіргі Қазақстан жеріне соғыс жылдарында қарсылас империялар - Австро-Венгрия мен Германиядан соғыс тұтқындары мен өз еркімен берілген (подданный) адамдар әкелінді. Бұл мемлекеттерден тұтқын есебінде келген азаматтарды Ресей империясының ішкі істер министрлігі Дала өлкесі мен Түркістанға да қоныстандырды. Соғыс тұтқындарының Қазақстан мен Түркістан өлкелеріне таралуының негізгі себебі, бұл аймақтар шекарадан алыс болды және ол аймақта жұмыс күшінің жетіспеушілігінің алдын алды. Орталық державалар қатарында болған Австро-Венгрия мен Германиядан келген тұтқындар Түркістан өлкесінің облыстары мен уездеріне де қоныстандырылды, алайда олардың саны Дала өлкесіне қарағанда аздау болды [28-38]. Соның ішінде, австро-венгриялық және неміс тұтқындар, Түркістан өлкесінің Сырдария облысына қарасты болған Әулиеата уезіне де жіберілді.

Материалдар және әдістер. Ғылыми жұмысты жазуда отандық және шетелдік ғалымдардың іргелі теориялық пікірлері мен тұжырымдары қолданыс тапты. Сонымен қатар архив қорларының материалдары ғылыми айналымға енгізілді. Ғылыми зерттеуді жүргізуде тарих ғылымының тарихисалыстырмалылық, тарихи жүйелеу әдістері пайдаланылды. Теориялық және методологиялық негіз ретінде, тарихи оқиғаларды баяндау кезінде, саяси тарихи процестерді қарастыруда тарих ғылымының заманауи және қосалқы әдістері қолданылды. Мұндай әдістер Әулиеата жеріне тұтқындардың жіберілуі мен соғыс кезінде өз еркімен келген азаматтардың келуін, әлеуметтік өмірін, тағдырын анықтауға мүмкіндік берді. Зерттеу жұмысын жазуда қазіргі кезде отандық және дүниежүзілік тарихты зерттеудегі принциптер негізге алынды. Бірінші Дүниежүзілік соғыс кезіндегі Антанта мүшелері мен Орталық державалардың саяси қатынастарына, тұтқындардың келуі мен олардың тағдырын сараптауда, адами факторларды анықтауда шынайылық, бейтараптық, жан-жақтылық, объективтілік көзқарастар мен ұстанымдар басты назарда болды.

Қазақстан жеріне австро-венгриялық және германдық тұтқындарды қоныстандырудың алғашқы шаралары. Қазіргі Қазақстан жеріне келген австро-венгриялық және германиялық соғыс тұтқындарының алғашқы легі Дала өлкесіне келумен басталды. Соғыс тұтқындарының алғашқы тобы Сібірге, Дала өлкесінің солтүстік-шығыс аймақтарына жіберіліп, олар 1914 жылдың тамызында келді. Еуропалық тұтқындар арасында Германия мен Австрия-Венгриядан келген азаматтар көп болды. Бірақ бұл кезде Дала өлкесі мен Түркістан тұтқындарды қабылдауға әлі толық дайын емес еді. Соғыстың бастапқы кезінде соғыс тұтқындарын қабылдау және орналастыру үшін арнаулы лагерлер болмады. Сондықтан алғашқы кезде бірқатар қиындықтар туындады. Тұтқындарға тамақ беру, жылы орындарға орналастыру оңай емес еді. Адамдар сарайларға орналастырылды, бір жерден екінші жерге жиі көшіріліп отырды. Ауа-райының қолайсыздығы мен азық-түліктің аздығынан, алғашқы кезде тұтқындар арасында өлім-жітім едәуір көп болды. 1915 жылдың көктеміне дейін қазіргі Қазақстан жерінде тұтқындарды ұстайтын арнаулы орындар жоқ еді. Осыған орай, соғыс тұтқындарын қабылдау үшін біртіндеп арнаулы орындар бөлінді, аз уақыт ішінде көптеген шешімдер қабылданып, тұтқындарды ұстайтын лагерлер құрыла бастады [1].

Соғыс жылдарындағы Қазақстанның Дала және Түркістан өлкесіндегі тұтқындардың саны және жай-күйіне салыстырмалы түрде тоқталып өтсек, онда көптеген ерекшеліктер болды. Майдандардағы қантөгіс шайқастар соғыс тұтқындарының бірден-ақ зор тасқынын туғызды, олар, ең алдымен, Дала өлкесіне қарасты болған Ақмола, Павлодар және Семей уездеріне көптеп жіберілді. Оның ішінде 
Ақмола облысына келген тұтқындардың қатары көп болды. Облыста өзге елдерден келген адамдардың саны күн санап артып отырды. Алғаш рет келімсектерді ұстауға арналған орындар да осы Ақмола облысында салынды. 1915 жылдың басында берілген мәліметтер бойынша, Ақмола облысының 150ден астам елдімекендерінде орналастырылған шетелдік тұтқындар саны 22 мыңнан астам деп көрсетілген [2]. Ақмола облысының ауылды жерлерінде 8,5 мыңнан астам тұтқын орналасқан. Мұндай үлкен көрсеткіштер Семей облысында да тіркелді. 1915 жылдың басында Семей облысына қарасты Семей, Өскемен, Зайсан, Павлодар уездерінде жалпы саны жеті мыңнан астам тұтқын боды, олардың арасында австро-венгриялық және германдық азаматтар бар еді [3].

Түркістан өлкесінде тұтқындарды қабылдау шаралары. Келесі кезекте Түркістан өлкесіне қарасты облыстардағы тұтқындарға тоқталсақ, олардың да саны аз болған жоқ. Бұған нақты мысал ретінде әскери-әкімшілік бөлініс бойынша Түркістан өлкесіне қарасты болған Қазақстанның оңтүстік аудандары, яғни Сырдария мен Жетісу облыстарының және Түркістан әскери округінің қыстақтарында қоныстанған соғыс тұтқындарын негізге алуға болады. Соғыстың алғашқы кездерінен бастап, Түркістан өлкесіне келген еуропалық әскери тұтқындар мен өлкені паналаған ерікті адамдар негізінен Сырдария облысына қарасты уездерге келе бастады. Сырдария облысының Қазалы, Перовск, Түркістан, Черняев, Әулиеата уездері әскери тұтқындарды қабылдаған негізгі аудандар қатарына саналды [4, 44-47 б.].

Бірінші дүниежүзілік соғыс жылдары Әулиеата уезі Түркістан өлкесіне қарасты болып, ол Ташкенттен басқарылды. Бұл кезде Ресей империясының әскери билігі тарапынан Түркістанда Түркістан (ТуркВО) әскери округі ұйымдастырылды, ол соғыс кезінде белсенді қызмет етіп, барлық соғыс мәселелері осы органның ықпалымен шешілетін еді. Осылайша, бұл орган өлкедегі тұтқын мәселелерімен де айналысты. Соғыс барысында тұтқындарды қабылдау, оларды орналастыру мен әлеуметтік қамсыздандыру жағынан үлкен қиындықтар туды.

Соғыстың алғашқы күндерінен-ақ Ресей империясының барлық аймақтарында Австро-Венгрия мен кайзерлік Германияның өз еркімен берілген азаматтары (подданные) жау саналды. Мұндай жағдай Әулиеата жерінде де байқалды. Саяси-әскери билік тарапынан Ресей империясының билігін мойындаған германдық және австро-венгриялық мұндай азаматтарға қысқа уақытта өзіндік ерекше жаңа тәртіптер қабылдануы әбден мүмкін еді. Мұның басты себептері Бірінші Дүниежүзілік соғыстың қарсаңында Австро-Венгрия мен кайзерлік Германияның Ресей империясына қарсы болуымен байланысты еді. Соғыс басталмай тұрып-ақ, Ресейдің әскери билігінің нұсқауы бойынша, жергілікті жерлерде барлық шетелдік азаматтарға және әскердегі тегі еуропалық болған әскери адамдарға қатаң бақылау орнатылды, олардың жүріс-тұрысы қадағаланды.

1914 жылы, 23 шілде күні Петербургтағы Бас Әскери Штабтың кеңсесінен телеграмма арқылы империялық әскер құрамындағы германдық азаматтарды тұтқын ретінде қабылдау жайлы нұсқау келді. Бұл нұсқау, алдымен облыстық әскери губернаторға келіп, онда бұрын Ресейге өз еркімен берілген германдық азаматтарды арнайы шешім шыққанға дейін өз бақылауында ұстау туралы бұйрық берілді. Бұдан соң аймақтағы бұрынғы германдық азаматтардың тізімі мен олардың саны туралы мәлімет сұралған. Мұның басты себебі, өз еркімен берілген (подданный) германдық азаматтардың арасында барлаушылар мен тыңшылар көп болуы мүмкін деген күмән басым болды [5]. Түркістан генералгубернаторлығының кеңсесінен облыстың әскери-губернаторына жолданған келесі бір нұсқаулықта Австро-Венгрия империясынан келген азаматтарға қатысты дәл осындай шараларды жүргізу қажет екені айтылды. Бұл құжатқа сол кездегі Түркістан әскери округін басқарған генерал-лейтенант В.Е. Флуг және басқалар қол қойды [6]. Нұсқаулыққа сәйкес, автро-венгриялық азаматтарға да германдықтар сияқты уақытша бақылау орнатылды.

Ресей билігі тарапынан мұндай саяси-әскери шаралар өте аз уақыт ішінде барынша жылдам жүзеге асырылды. Ол бойынша, өлкеде тәртіп барынша күшейтілді. 28 шілде күні соғыс басталып, Ресей империясы соғыстың негізгі қатысушысына айналған соң, Түркістанға қатысты жұмыстар барынша қызу түрде ұйымдастырылды. 30 шілде күні Ресей империясының Ішкі істер министрінің көмекшісі, әскери қолбасшы В.Ф. Джунковский тарапынан бұйрық келіп, онда Түркістанда 18-45 жас аралығында мылтық және басқа да қару асына алатын ер азаматтарды тұтқын есебінде қабылдап, оларды қатаң бақылауда ұстау туралы нұсқау берілді. Сонымен бірге оларды басқа жақтарға көшіру туралы шешімдер қарастырылды [7].

Дегенмен, уақыт өте Ресей билігінің Түркістанда тұратын, азаматтық қабылдап, империялық билікті мойындаған Австро-Венгриядан келген азаматтарға арнап қабылданған алғашқы қатаң бақылау шаралары аздап жеңілдетілгендей болды. Оның басты себептерінің бірі - Австро-Венгриядан келген азаматтардың ішінде орыстар, чехтар, сербтер мен словактар болды. 1914 жылдың 14 тамызында Петербургтан құпия телеграмма жолданып, онда австро-венгриялық азаматтарға шетелге шығуға, 
соғыс майдандарына жақындауға және ешқандай тәртіпсіздік жасамау талап етілді [8]. Мұнда Ресей билігінің славян халықтарына деген өзіндік жақындық пен жеңілдік көрсетуге тырысқаны анық көрініп тұр.

Соғыс кезінде Түркістан өлкесіне келген әскери тұтқындардың саны аз болған жоқ. 1915 жылдың маусым айына қарай, ресми мәліметтер бойынша, өлкедегі әскери тұтқындардың саны 148 мың адамнан асты. Олар арнайы құрылған лагерлерде, казармаларда және басқа адамдар үшін жедел түрде бейімделген ТуркВО-ның өзге бөлімшелеріне орналастырылды. Ғалымдардың көрсетуі бойынша, 1915 жылы Түркістан өлкесіне Австрия-Венгриядан - 82 425, ал Германиядан 3812 тұтқын келген $[9,49$ б.].

1914-1915 жылдары Түркістан өлкесіне әскери тұтқындармен бірге, «Азаматтық тұтқындар» немесе «әскери атағы жоқ тұтқындар» деп аталатын 300-350 адам әкелінді. Бұлар - Ресей әскерлері соғыс аймақтарынан шығарып алған және өз еркімен берілген (подданые) Австрия-Венгрия мен Германияның азаматтары еді. Бастапқыда (бірнеше ай) олар жергілікті тұрғындардан оқшауланған болса да, кейіннен олардың көпшілігі белгілі деңгейде еркіндік ала бастады. 1916 жылдың ортасында «азаматтық тұтқындардың» көпшілігі қауіпсіздік орындарынан босатылып, полицияның бақылауында болды және кету құқығынсыз өмір сүрді. Сондықтан олар, әсіресе, жұмыс істейтіндер, уақытының едәуір бөлігін тұрғылықты жерлерінен тыс жерде өткізіледі.

Сонымен қатар Түркістан өлкесінде еуропалықтардың көбеюіне соғыстан қашқан босқындар да ықпал етті. 1915 жылдың шілдесінен бастап аймаққа босқындар да келе бастады. Нәтижесінде аймақта шамамен 7-8 мың босқын тіркелді. Түркістандағы тұтқындардың шоғырлануы, содан кейін босқындардың келуі жергілікті халықтың материалдық жағдайын едәуір нашарлатып, азық-түлік пен тұрғын үй дағдарысына әкелді. Олар да кей жағдайда өз еркімен берілген (подданые) азаматтар есебінде қабылданды. Осылайша, 1916 жылдың басында аймақтағы әскери тұтқындардың жалпы саны 200 мыңға жетті. Олардың саны көбейіп, орналасқан қалаларынан да тыс аумақтарды қамти бастады. Өлкелік билік бұған қатты алаңдады, өйткені кез келген уақытта тәртіпсіздік туындап, олар жағдайды ушықтыруы мүмкін еді.

Осылайша, Австро-Венгрия мен Германиядан келген әскери тұтқындар мен азаматтардың және босқындардың көбеюі өлкеде әлеуметтік қиындықтар тудыра бастады. Түркістан генерал-губернаторы Ф.В. Мартсон түрмедегі әскери тұтқындарды Түркістаннан шығару туралы өтініш білдіріп, халықтың наразылығын, экономикалық жағдайдың нашарлауын, өте қиын жағдайларды (соның ішінде климатты қоса) және тұтқыннан қашу фактілерінің көбеюін алға тартты. Өйткені жергілікті тұрақты әскери құрамалардың майдан мен тылға кетуіне байланысты, тұтқындарды қорғайтын адамдардың қатары азайған. Соғыстың алғашқы жылдарында Түркістанда германиялық және австро-венгриялық тұтқындардың саяси-әлеуметтік жағдайы осындай дәрежеде болды [9, 49-50 б.].

Әулиеата уезіндегі германдық және австро-венгриялық тұтқындар. Аталып отырған жағдайлар соғыс басталар сәттен бастап, Әулиеата уезінде де орын алды. Соғыс кезінде Әулиеата жеріне тұтқынға түсіп келген халықтардың бірі - немістер және ұлты өзге басқа да германиялық азаматтар болды. Олар негізінен Германиядан және Австро-Венгриядан келді. Жалпы, немістер үшін Орта Азия мен Түркістан өлкесі бұрыннан таныс еді. Оның басты мысалы ретінде немістердің Бірінші Дүниежүзілік соғысқа дейін және соғыс жылдарында да Қазақстанға көптеп көшіп келуін айтуға болады. Олардың үлкен бөлігі Ресей империясының Еуропа мемлекеттерімен шекаралас аймақтар мен империяның ішкі аудандарынан Қазақстан жеріне көшіп келіп, соның ішінде Әулиеата уезіне де қоныстанды. Олардың басты тіршілігі жер және мал шаруашылығы болып, Әулиеата өңірінде халық шаруашылығын [10] дамытты. Соғыс кезінде Түркістанға, соның ішінде Әулиеата уезіне Ресейдің басқа аймақтарынан неміс қоныстанушылары (переселенцы) көшіп келіп жатса, екінші бір жағынан еуропалық немістер де көшіп келіп жатты [11].

Соғыстың алғашқы күндерінен бастап Әулиеата уезі соғыс тұтқындарының аса ірі лагеріне айналмаса да, аймақта Австро-Венгрия мен Германиядан келіп, кейіннен тұтқын саналған азаматтар аз болған жоқ. 1914 жылы 23 тамыз күні Әулиеата уезінің Николайполь елдімекеніне келген екі германиялық азаматтың есімдері аталады. Олар:

1. Освальд Гергольд.

2. Рудольф Бонь болды [12].

Жалпы, Әулиеата уезіне қарасты болған Николайполь учаскесінде немістер бұрыннан өмір сүріп келе жатқан болатын. Бірақ, жоғарыда аталғандай, олар жергілікті немістер, яғни Ресей империясының азаматтары саналып, жергілікті халықпен араласып, етене өмір сүрді. Олар алғашқыда осы учаскеде қалатын болып, алайда тұтқын саналған германиялық бұл азаматтарды көп ұзамай, басқа ауданға көшіру қарастырылды және Верный қаласына қоныс аударатын болды. Освальд Гергольд пен 
Рудольф Бонь арнайы бақылайтын ішкі әскердің көмегімен жеткізілетін болды [13]. Бұл азаматтар Верный қаласына көшірілмесе де, олардың жергілікті халықтан бөлек тұратыны анық еді. Биліктің тұтқындарды жергілікті халықтан бөлек ұстауының өзіндік себептері болып, ол германиялық тұтқын азаматтардың жергілікті немістерді арандатуы мүмкін деген күдікпен сипатталды.

Дәл осы сияқты Әулиеатадағы германдық тұтқындар Адольф Визе мен Артур Целе және АвстроВенгриялық Георг Лехнер Верный қаласына қоныс аударды. Олар да алғашқыда Әулиеата уезіне әкелініп, кейіннен басқа жаққа қоныс аударды [14]. 19 қыркүйек күні аталған азаматтардың Верныйға орналастырылғаны туралы Әулиеата уезіне мәлімет жіберілді. Дегенмен де Түркістан өлкесіне, оның ішінде Сырдария облысында тұтқын саналған еуропалық азаматтардың арасынан қызметке адалдығы мен жеке бастарының тәртібіне қарай, билік оларға түрлі жеңілдіктер жасады [15].

1914 жылы қыркүйек айындағы мәлімет бойынша, Әулиеата уезінде әскери тұтқын деп саналған жалпы саны 11 азамат болды. Олардың жартысына жуығы Верныйға аттандырылып, қалғаны әртүрлі жағдайда Әулиеата уезінде күн кешті. Әулиеатада қалған бір германиялық азамат, шыққан жері Бавариядан болған Яков Губер мен Австро-Венгриядан келген азаматтар болды. Әулиеатада қалған Австро-Венгриядан келген азаматтардың ұлты чехтар мен словактар болды [16]. Тегі славян болып, орыс тілін білген тұтқындардың мүмкіндігі көп болды. Австро-Венгриядан Түркістанға келіп, кейіннен әскери тұтқын саналған азаматтардың үлкен бөлігі славян тектес халықтар еді. Өз кезегінде, жүрістұрысы мен тәртібіне қарай, оларға жеңілдіктер де қарастырылды. Империялық билік тарапынан Түркістан әскери округіне қарасты аймақтардағы тұтқындар арасынан славян тектес ұлт өкілдеріне жеңілдіктер көрсетілумен қатар, материалдық көмек көрсетілу де басшылыққа алынды [17].

Германиялық тұтқындардың Әулиеатаға келуі мен олардың сол аймақта біраз тұрақтап, артынша басқа облыстарға кету жағдайлары кейінгі жылдары да орын алды. 1915 жылы алғашқы айдан бастап мұндай істер жалғасты. Қаңтар айында германиялық азамат, кейіннен тұтқын ретінде қабылданған Витольд Гольскойдың өзінің денсаулығына байланысты өтініш білдіріп, біраз қиындықтардан аман қалған [18]. Тіпті оның белгілі бір уақыт аралығында Ташкент қаласында абақтыда болғаны туралы мәліметтер де тіркеліп, [19] ол Витольд Гольскойдың сыртқы әскери күштермен байланысы болды деген күдіктің негізінде жүзеге асырылған. Алайда көп ұзамай, ол 1915 жылдың наурыз айында босатылып, содан соң Әулиеата уезінің әскери басшылығына өзінің Верный қаласына бармай, Әулиеатада қалғысы келетіні туралы үлкен өтінішін білдіреді. Бұл өтініш қабылданып, Витольд Гольской Әулиеатада қалатын болды.

Дәл осындай өтініштер 1915 жылдың шілде айында әскери тұтқын саналған германиялық азаматтар Фердинанд Иоганн, ағайынды Яков және Генрих Гердеменстер өздерінің тіршілігін Әулиеатада жалғастыруды сұрап, алайда олардың мұндай арыз-тілектері орындалмады. Олар Әулиеата қаласында біраз тұрып, Жетісу облысына жер аударылды [20].

\section{Соғыстың алғашқы жылдарынан бастап Әулиеата уезіне келген Австро-Венгрия мен Германия} азаматтары

\begin{tabular}{l|l|l|l|l}
\hline № & Аты-жөні & Ұлты & Келген мемлекеті & Жасы \\
\hline 1 & Дулла Йосиф Иванович & Чех & Австро-Венгрия & 48 \\
\hline 2 & Фабри Йосиф Йосифович & Чех & Австро-Венгрия & 23 \\
\hline 3 & Дулла Иван Иванович & Чех & Австро-Венгрия & 35 \\
\hline 4 & Фон Зибенгюнер Антонович & Чех & Австро-Венгрия & 62 \\
\hline 5 & Брна Иван Иванович & Чех & Австро-Венгрия & 21 \\
\hline 6 & Губер Яков Яковлевич & Неміс & Германия & 38 \\
\hline
\end{tabular}

1915 жылы көктемде Әулиеата уезінде жалпы саны 5 мыңдай тұтқын болды, олар - әртүрлі соғыс майдандары мен тылдан қашқандар еді. Әрине, олардың арасында аз да болса Германия мен Австро-Венгрияның тұтқындары өзіндік белгілі бір көрсеткішке ие болды. 1915 жылдың мамыр айында тұтқындардың тұратын жері мен орны, олардың жай-күйі туралы арнайы шешімдер қабылданды. Ол бойынша тұтқындар жылы орындарға көшірілетін болды және әлеуметтік жағдайы дұрыстау күйге келетін болды [21].

1915 жылдың соңына қарай Түркістан өлкесінің басшылығы тарапынан уездердегі өмір сүріп жатқан еуропалық тұтқындардың саны мен ұлты бойынша мәлімет жинау тапсырылады. Бұл жағдай өлкеде өзге ұлттардың санын, олардың қаншалықты өмір сүріп жатқанын, сондай-ақ олардың әлеуметтік деңгейі туралы мәліметтер жинаудың үлкен бір бастамасы еді [22]. Өз кезегінде, бұл, мемлекеттік ішкі саясатпен байланысты болып, елде өзге ұлт өкілдерінің саяси қызметі мен жұмыстарын анықтау еді. Көрсетілген кестеде Әулиеата уезінде түбегейлі тұрақтап, Верныйға немесе басқа аймақтарға қоныс аудармаған азаматтардың есімдері берілген. Айта кетерлігі, бұл адамдар - 
Әулиеатаға келген тұтқындар арасынан белсенді түрде көзге түскен азаматтар және олар бүкіл тұтқындардың санын көрсетпейді. Жоғарыда аталғандай, Әулиеата жерінде еуропалық ұлт өкілдерінен тұратын тұтқындар мен азаматтардың тобы аз болған жоқ. Олардың негізгі бөлігі Әулиеата қаласы мен Меркіде тұрды.

Түркістанда тұтқындарды түгендеу жұмыстары кейіннен де көптеп ұйымдастырылатын болды. Мұндай мәліметтерді жинаудың тағы бір негізгі себебі Ресейдің ішкі аудандарында тұтқында жүрген азаматтар арасынан тыңшылардың шығып отыруымен де байланысты еді. Соғыс кезінде Түркістан өлкесінде Магендр Пратап есімді германдық тыңшы жұмыс істеген және ол Түркістан туралы Германияға ақпарат жеткізіп отырған. 1917 жылы мамыр айында Сырдария облысының әскеригубернаторы тарапынан, Әулиеата уезінің басқармасына осы тыңшының Әулиеата жерінде болуы мүмкін деген күдікпен, арнайы тапсырма берілген. Жалпы, соғыс кезінде өз еркімен берілген (подданный) азаматтар арасынан мұндай тыңшылар көптеп шығып отырған [23].

Кеңес үкіметі және Әулиеатадағы тұтқындардың саяси тағдыры. 1917 жылы Ресей империясында орын алған екі бірдей төңкеріс мемлекеттегі саяси жағдайды түбегейлі өзгертіп жіберді. 1917 жылғы Қазан төңкерісінен кейін билікке келген большевиктер партиясы Ресейдің Бірінші Дүниежүзілік соғыстан шығатынын жариялады. Ресейдің соғыстан шығуы мен 1918 жылы елде басталған Азамат соғысы мемлекеттегі жатжерлік соғыс тұтқындарының саяси тағдырына елеулі түрде әсер етті. Ол әртүрлі сипатта көрініс тауып, негізгісі - большевиктер мен тұтқындар арасындағы өзара жақындық орнауы болды. Большевиктер мемлекеттегі барлық органдарды қолға алуда және Ресейде империялық жүйені жоюда жергілікті халықпен бірге, шетелдік тұтқындарды да өзіне тартты. Империяның орталық губернияларында ауқымды түрде орын алған сендіру мен халық арасында үгіттеу жөнінен, большевиктердің орасан зор практикалық тәжірибесі болған революциялық оқиғалар соғыс тұтқындарының да таптық санасын оятты, олардың әлеуметтік аражігінің ашылу үрдісін тездетті, майдандардағы қантөгісті қырғынның апатты зардаптарын ұғынуына себеп болды. Азамат соғысы кезінде, түрлі соғыс қимылдарына соғыс тұтқындары да тартылды.

Ескерерлік жайт, Ресей империясында большевиктер партиясы билікке келіп, ескі империялық жүйе жойылып, барлық халықтар мен ұлттарға теңдік жариялан соң, өзге аймақтардағы сияқты, Әулиеата уезінде де бұрын белгісіз болған адамдардың есімдері тізімге іліне бастады. Дәлірек айтқанда, бұрын өз аты-жөндерін жасырып, бой тасалап жүрген адамдар жарыққа шығып, соның негізінде Австро-Венгрия мен Германиядан келген адамдар арасында «жаңа есімдер» пайда болды. Мұндай жағдайлар өзге ұлттар арасында көптеп орын алды. Басқа аймақтардан келіп қосылып жатқандар да болды. Тұтқындарға арнайы азаматтық статусын беріп, оларды қоғамның белгілі бөлшегі ретінде қарады. Бұл жағдай, әрине, мемлекетте өзге ұлт өкілдерінің саны мен олардың Қазақстанға келу тарихын анықтауға үлкен мүмкіндік берді [24].

Жоғарыда Әулиеата уезі бойынша германдық және австро-венгриялық тұтқындар тек Әулиеата қаласы мен Меркіде ғана болды десе, енді басқа болыстар мен елдімекендердің аты атала бастады. Бұған төмендегі кестеде берілген Германия мен Австро-Венгриядан келген тұтқындардың тізімі куә бола алады. Тұтқындар бұқарасы тарапынан саяси белсенділіктің өсуіне поляктардың, болгарлардың, сербтердің және басқалардың социал-демократиялық ұйымдарының құрылуы қолайлы жағдай жасады. Әдетте жергілікті большевиктер соғыс тұтқындары ішіндегі белсенділерді революциялық қозғалысқа тартуға тырысты және оларды барынша өз ықпалдарында ұстауға ұмтылды. Соның ішінде Әулиеата өңіріне Австро-Венрия мен Германиядан келген тұтқындар да мемлекеттік саясаттың назарына іліге бастады [25].

Осылайша, Әулиеата қаласы мен болыстарда тұтқында ұсталған азаматтардың тағдыры түбегейлі өзгерді. 1919-1920 жылдары Әулиеата уезінде бұрын тұтқында болған азаматтарға бостандық беріліп, олар да өзге кеңес азаматтары сияқты еркін өмір сүретін болды. Барлық елдімекендер бойынша олардың тізімі жасалып, ендігі өмірлері туралы талқыланды және тиісті шешімдер шығарылды. Оның басты мысалдарының бірі - 1920 жылы 24 тамызда Әулиеата қаласының Ұлттық істер бойынша секция басшылығының барлық болыстарда тұтқындар тізімінде тұрған өзге ұлттардың тізімін сұратып, олардың барлығын толықтай тіркеуден өткізіп, есепке қабылдауы туралы бұйрығы. Мұндай шаралар өзге уездерде де жүргізілді. Казанский және Благовещенск уездерінде болған бұрынғы тұтқындардың да тізімдері жасалып, ол уездік Ұлттық істер секциясына өткізілді [26].

Кестеде көрініп тұрғандай, Австро-Венгриядан келген азаматтардың үлкен бөлігі славян ұлтының өкілдері болып тұр. Әулиеатада бұрын есімдері белгісіз болған бұл азаматтар, соғыс аяқталып, Түркістанда большевиктердің өзге ұлттарға бостандық жариялағанына дейін, жергілікті орыстармен, украиндармен етене араласып күн кешкен. Себебі, тұтқындарды басқа аймақтарға көшіру олар үшін қауіпті саналған. Жалпы, Әулиеата жерінде тұрып, сонда тұтқын болған германиялық және 
австро-венгриялық азаматтарға қатысты туған ең үлкен қиындық - олардың Жетісу мен басқа аймақтарға көшіру жұмыстары еді. Оның басты себептері, екі мемлекеттен де келген тұтқындардың неміс және орыс тілдерінен хабары болып, жергілікті немістермен және славян тектес халықтармен ауыз біріктіріп, арандату жұмыстарын жүргізуі мүмкін деген күмәннің болуымен байланысты.

\section{Әулиеата уезінің Петровск, Казанский және Благовещенск болыстарына тұтқын болып келген Австро- Венгрия және Германия азаматтарының тізімі}

\begin{tabular}{|c|c|c|c|c|}
\hline № & Аты-жөні & Ұлты & Келген мемлекеті & Жасы \\
\hline 1 & Осиф Симчук & & Австро-Венгрия & 29 \\
\hline 2 & Григорий Мартынский & Русин & Австро-Венгрия & 27 \\
\hline 3 & Василий Голешино & Русин & Австро-Венгрия & 31 \\
\hline 4 & Людвиг Кешери & Венгр & Австро-Венгрия & 41 \\
\hline 5 & Михаил Царь & Русин & Австро-Венгрия & 41 \\
\hline 6 & Григорий Ардилянц & Румын & Австро-Венгрия & 31 \\
\hline 7 & Алексей Брондиль & Румын & Австро-Венгрия & 35 \\
\hline 8 & Иван Бырлин & Румын & Австро-Венгрия & 28 \\
\hline 9 & Фердинанд Весяк & Неміс & Австро-Венгрия & 27 \\
\hline 10 & Алекесей Фозекош & Венгр & Австро-Венгрия & 31 \\
\hline 11 & Федор Бучин & Неміс & Германия & 29 \\
\hline 12 & Илья Мреглот & Русин & Австро-Венгрия & 36 \\
\hline 13 & Петр Алейников & Поляк & Австро-Венгрия & 36 \\
\hline 14 & Юзик Пильный & Поляк & Австро-Венгрия & 30 \\
\hline 15 & Йосиф Ковалик & Поляк & Австро-Венгрия & 47 \\
\hline
\end{tabular}

Қорытынды. Бірінші дүниежүзілік соғыс жылдарында Әулиеата және онымен іргелес аудандарда, сондай-ақ қазіргі Қазақстанның басқа да аймақтарында Австрия-Венгрия мен Германияның соғыс тұтқындарының келуіне байланысты қарастырылып отырған кезеңде, өлкенің қоғамдық-саяси өмірі елеулі өзгерістерге ұшырады. Басқа жағдайларға қоса, мәселені көрсетудің маңыздылығын осы ортадан кейіннен Азамат соғысына белсене қатысқан тағдыры ерекше адамдардың шығуымен түсіндіруге болады. Олардың басым бөлігі, тәжірибелі әскерилер - Қызыл Армия жауынгерлерінің немесе оның қарсыластарының отрядтарына кіріп, кең-байтақ қазақ өлкесін де қамтыған алапат шайқастардың от-жалынына қызу араласты, кешегі көшпелі елдің мыңдаған адамдарын әскери өнерге төзімділікпен үйрете алатын нұсқаушылар өте қажет болған жергілікті жерлерде, таяуда ғана құрылған ұлттық қарулы құрамалардың отрядтары қатарына қосылды. Киелі Әулиеата жері де өзге аймақтар сияқты, өз кезегінде, Бірінші Дүниежүзілік соғыс жылдарында талай жанға пана бола алды. Еуропалық соғыс майдандарынан жан сауғалап қашқан германиялық және австро-венгриялық азаматтар енді тұтқын деп саналып, одан кейінгі өмірлерін сонау алыс Түркістанда, оның ішінде Әулиеата жерінде жалғастырды. Әулиеата уезінде бұрынғы кезден Ресей империясының ішкі аудандарынан келген жергілікті еуропалық ұлт өкілдерінің, оның ішінде немістер мен славян халықтарының көп шоғырлануы соғыс тұтқындарының бұл өңірді жатсынбай, тез сіңісіп кетуіне ерекше ықпал етті.

Мақалаға сілтеме: Әпендиев Т. Ә., (2020). Бірінші дүниежүзілік соғыс жылдарында Әулиеата уезіндегі Германия және Австро-Венгрия тұтқындары. Challenges of Science. Issue III, p.: 83-90. https://doi.org/10.31643/2020.012

\section{References / Пайдаланған әдебиеттер тізімі}

[1] ҚРОМА. 369. қ., 1, тізбе, 4842. іс, 6-7 п.

[2] ҚРОМА. 369. к., 1, тізбе, 4842. іс, 60-64 п.

[3] ҚРОМА. 369. к., 1, тізбе, 4842. іс, 114-116 п.

[4] Касымбаев Ж.К. Германские военнопленные периода Первой Мировой войны в Казахстане (социальнодемографический аспект) // История немцев Центральной Азии. Материалы международной научной конференции. - Алматы, 1998. - С. 44-52.

[5] ҚРОМА. 146 к., 1 тізбе, 1 іс, 1 п.

[6] ҚРОМА. 146 қ., 1 тізбе, 1 іс, 4 п. 
[7] ҚРОМА. 146 к., 1 тізбе, 1 іс, 5 п.

[8] КРОМА. 146 к., 1 тізбе, 1 іс, 12 п.

[9] Котюкова Т.В. Туркестанский плен: Немецкие и Австро-Венгерские военнопленные в Русском Туркестане в годы Первой мировой войны. // Россия и современный мир. - 2017. - №3. - С. 47-64.

[10] Apendiyev T.A., Asylbekova Z.M., Abdukadyrov N.M., Satov, E.Z. A historical picture of German resettlement to Kazakhstan (End of the 19th Century-Beginning of the 20th Century) // Herald of the Russian Academy of Sciences, 86(6), 534-536. https://doi.org/10.1134/s1019331616060174

[11] T.A. Apendiyev, S.S. Zhandybaeva, T.A. Tulebaev, K.E. Abykenova. The Migration of Germans to Kazakhstan in the end of XIX - beginning XX century. Bylye Gody, 2017, Vol. 44, Is. 2. 568-575 p.

[12] ҚРОМА. 146 к., 1 тізбе, 1 іс, 13 п.

[13] ҚРОМА. 146 к., 1 тізбе, 1 іс, 15 п.

[14] ҚРОМА. 146 қ., 1 тізбе, 1 іс, 20 п.

[15] ҚРОМА. 146 к., 1 тізбе, 1 іс, 26 п.

[16] ҚРОМА. 146 қ., 1 тізбе, 1 іс, 28 п.

[17] ҚРОМА. 146 к., 1 тізбе, 1 іс, 42 п.

[18] ҚРОМА. 146 к., 1 тізбе, 1 іс, 38 п.

[19] ҚРОМА. 146 к., 1 тізбе, 1 іс, 56-57 п.

[20] ҚРОМА. 146 қ., 1 тізбе, 1 іс, 106 п.

[21] ҚРОМА. 146 к., 1 тізбе, 1 іс, 85 п.

[22] ҚРОМА. 146 к., 1 тізбе, 1 іс, 119 п.

[23] ҚРОМА. 146 қ., 1 тізбе, 1 іс, 139 п.

[24] ЖОМА (Жамбыл облысының Мемлекеттік Архиві) 50 к., 1 тізбе, 49 іс, 58 п.

[25] ЖОМА. 50 қ., 1 тізбе, 49 іс, 64 п.

[26] ЖОМА. 50 к., 1 тізбе, 49 іс, 71-72 п.

[27] Apendiyev T.A.Abdukadyrov N.M.; Kubeyev R.D. History of German Diaspora in Kazakhstan in the Context of Migration System // Bulletin of the Georgian National Academy of Sciences. Volю 13, Issue 4, 2019, Pages 127-134

[28] Apendiyev T.A., \& Abdukadyrov N.M. (2020). During the first world war germany and austria - hungary prisoners of the aulieata county. The Bulletin, 1(383), 218-225. https://doi.org/10.32014/2020.2518-1467.27

[29] Akhmetova A., Toktaubay A., Kassymova G., Apendiyev T., (2020). Issledovaniye problemy formirovaniya dukhovno-nravstvennykh kachestv starsheklassnikov [Study of the problem of the formation of spiritual and moral qualities of high school students]. Challenges of Science. Issue III, p.: 76-82. https://doi.org/10.31643/2020.011

[30] Apendiyev, T. A., Smagulov, B. K., Kozybayeva, M. M. (2019). Study of some subethnic and genealogical groups of Kazakhs in pre-revolutionary Russian historiography (XVIII - early XX century). The Bulletin, 6(382), 346-354. https://doi.org/10.32014/2019.2518-1467.180

[31] Kenzhaliev B.K., Kul'deev E.I., Luganov V.A., Bondarenko I.V., Motovilov I.Y., Temirova S.S. (2019). Production of Very Fine, Spherical, Particles of Ferriferous Pigments from the Diatomaceous Raw Material of Kazakhstan. Glass and Ceramics, 76(5-6), 194-198. https://doi.org/10.1007/s10717-019-00163-w

[32] Triyono, B.M., Mohib, N., Kassymova, G.K., Pratama, G.N.I.P., Adinda D., Arpentieva, M.R. (2020). The Profile Improvement of Vocational School Teachers' Competencies. Vysshee obrazovanie v Rossii $=$ Higher Education in Russia. Vol. 29, no. 2, pp. 151-158. https://doi.org/10.31992/0869-3617-2020-29-2-151-158

[33] Gasanova R.R. Kassymova G.K., Arpentieva M.R., Pertiwi F. D., Duisenbayeva Sh. S., (2020). Individual educational trajectories in additional education of teachers. Challenges of Science. Issue III, p.: 59-68. https://doi.org/10.31643/2020.009

[34] Kassymova, G.; Triyono, B.; Dossayeva, S.; Akhmetova, A. (2019), Cognitive competence and electronic learning. "Challenges of Science". Issue II, 2019. Page 153-158. https://doi.org/10.31643/2019.030

[35] Апендиев, Т. А., Асылбекова, Ж. М., Абдукадыров, Н. М., \& Сатов, Е. Ж. (2016). Историческая картина переселения немцев в Казахстан (конец XIX - начало XX вв.). Вестник Российской Академии Наук, 86(12), 1154-1156. https://doi.org/10.7868/s0869587316150019

[36] Apendiyev, T.A.; Zhandybaeva, S.S.; Tulebaev, T.A.; Abykenova, K.E. (2017). The Migration of Germans to Kazakhstan in the end of XIX -beginning XX century. Bylye Gody, Volume 44, Issue 2, 2 June 2017, Pages 568575. https://doi.org/10.13187/bg.2017.2.568

[37] Abdukadyrov N.M., Ibragimovna K.A., UaltayevaShow A.S., Apendiyev T. A., Satov E.Z. (2016), Historical picture of the German people migration to Kazakhstan (end of the XIX and the beginning of the XX centuries). Man In India, 96 (10): 4015-4026

[38] Kudaibergenova A., Zhugenbayeva G., Apendiyev T., Chatybekova K., BissembayevaL., Aynagul K., Kymbat S. (2017). Influence of Migration Processes on Changing in the Ethnic Composition of the Population of Kazakhstan (End of the XIX - End of the XX Centuries), Man In India, 97 (2):47-64 